\title{
Effects of physical exercise on the cartilage of ovariectomized rats submitted to immobilization
}

\author{
Efeitos do exercício físico sobre a cartilagem de \\ ratas ooforectomizadas submetidas à imobilização
}

\author{
José Martim Marques Simas ${ }^{1}$, Regina Inês Kunz ${ }^{1}$, Rose Meire Costa Brancalhão, \\ Lucinéia de Fátima Chasko Ribeiro ${ }^{1}$, Gladson Ricardo Flor Bertolini ${ }^{1}$
}

\begin{abstract}
Objective: To analyze the effects of physical exercise on cartilage histomorphometry in osteoporosis-induced rats subjected to immobilization. Methods: We used 36 Wistar rats that were separated into six groups: G1, G2 and G3 submitted to pseudo-oophorectomy, and G4, G5 and G6 submitted to oophorectomy. After 60 days at rest, G2, G3, G5 and G6 had the right hind limbs immobilized for 15 days, followed by the same period in remobilization, being free in the box to $\mathrm{G} 2$ and G5, and climb ladder to G3 and G6. At the end of the experiment, the rats were euthanized, their tibias bilaterally removed and submitted to histological routine. Results: There was significant increase in thickness of the articular cartilage $(F(5 ; 29)=13.88 ; p<0.0001)$ and epiphyseal plate $(F(5 ; 29)=14.72 ; p<0.0001)$ as the number of chondrocytes $(F(5 ; 29)=5.11 ; p=0.0021)$ in ovariectomized rats, immobilized and submitted to exercise. In the morphological analysis, degeneration of articular cartilage with subchondral bone exposure, loss of cellular organization, discontinuity of tidemark, presence of cracks and flocculation in ovariectomized, immobilized and free remobilization rats were found. In ovariectomized and immobilized remobilization ladder rats, signs of repair of the cartilaginous structures in the presence of clones, pannus, subcortical blood vessel invasion in the calcified zone, increasing the amount of isogenous groups and thickness of the calcified zone were observed. Conclusion: Exercise climb ladder was effective in cartilaginous tissue recovery process damaged by immobilization, in model of osteoporosis by ovariectomy in rats.
\end{abstract}

Keywords: Osteoporosis; Immobilization; Exercise therapy; Physical therapy modalities; Rats, Wistar

\section{RESUMO}

Objetivo: Analisar os efeitos do exercício físico sobre a histomorfometria da cartilagem de ratas induzidas à osteoporose e submetidas à imobilização. Métodos: Foram utilizadas 36 ratas Wistar separadas em seis grupos: G1, G2 e G3 submetidas à pseudo-ooforectomia e G4, G5 e G6, à ooforectomia. Após 60 dias em repouso, G2, G3, G5 e G6 tiveram o membro posterior direito imobilizado por 15 dias, seguido pelo mesmo período em remobilização, sendo livres na caixa para G2 e G5, e de subida em escada para G3 e G6. Ao final do experimento, as ratas foram eutanasiadas, e suas tíbias foram retiradas bilateralmente $\mathrm{e}$ submetidas à rotina histológica. Resultados: Houve aumento significativo de espessura da cartilagem articular $(F(5 ; 29)=13,88 ; p<0,0001)$ e da placa epifisária $(F(5 ; 29)=14,72 ; p<0,0001)$, bem como do número de condrócitos $(F(5 ; 29)=5,11 ; p<0,0021)$ em ratas ooforectomizadas, imobilizadas e submetidas ao exercício em escada. Nas análises morfológicas, verificaram-se degeneração da cartilagem articular com exposição de osso subcondral, perda da organização celular, descontinuidade da tidemark, presença de fissuras e floculações em ratas ooforectomizadas, imobilizadas e com remobilização livre. Nas ratas ooforectomizadas, imobilizadas e com remobilização em escada, observaram-se sinais de reparação das estruturas cartilaginosas com presença de clones, pannus, invasão de vasos sanguíneos subcorticais na zona calcificada, aumento da quantidade de grupos isógenos e espessura da zona calcificada. Conclusão: 0 exercício físico de subida em escada mostrou-se efetivo no processo de recuperação do tecido cartilaginoso danificado pela imobilização, em modelo de osteoporose por ooforectomia em ratas.

Descritores: Osteoporose; Imobilização; Terapia por exercício; Modalidades de fisioterapia; Ratos Wistar

\footnotetext{
Universidade Estadual do Oeste do Paraná, Cascavel, PR, Brazil.

Corresponding author: Gladson Ricardo Flor Bertolini - Rua Universitária, 2.069 - Jardim Universitário - Zip code: 85819-110 - Cascavel, PR, Brazil - Phone: (55 45) 3220-3157

E-mail: gladsonricardo@gmail.com

Received on: June 18, 2015 - Accepted on: Sept 30, 2015

Conflict of interest: none.

DOI: 10.1590/\$1679-45082015A03418
} 


\section{INTRODUCTION}

Menopause leads to a slow and gradual decrease of estrogen and progesterone, which increases bone resorption and decreases calcium absorption by bone tissue. This results in more fragile bones and increased predisposition to the onset of diseases, such as osteoporosis $^{(1,2)}$ and osteoarthritis. ${ }^{(3)}$ Decreasing levels of estrogen shorten the half-life of cartilage and increase erosion of the cartilage surface, ${ }^{(4)}$ and this animal model has been a useful tool in studies investigating cartilage damage after ovariectomy. ${ }^{(5)}$

Immobilization is frequently used in musculoskeletal injuries, and can cause serious damage to the musculoskeletal system, particularly to the articular cartilage, resulting in temporary or permanent disability of the subject and increasing health care costs. ${ }^{(6,7)}$ Different treatments were proposed for rehabilitation after immobilization. However, exercise is preferred for improving muscle strength, preventing fractures and promoting tissue repair in the muscle, bone and cartilage. ${ }^{(7-11)}$

The rationale for this study considers the increased life expectancy of the population, the understanding that menopause can lead to some diseases, such as osteoporosis and osteoarthritis (very relevant public health issues), the disabilities and deleterious effects of immobilization on the tissue structure, and the need to gather scientific evidence for therapies commonly used in clinical practice.

\section{OBJECTIVE}

To assess the effects of exercise on cartilage histomorphometry in female rats with induced osteoporosis subjected to immobilization.

\section{METHODS}

\section{Experimental groups}

We used 36 female nulliparous adult (10 2 weeks) Wistar rats, with mean weight of $317.2 \pm 22.1 \mathrm{~g}$, kept in polypropylene cages, ad libitum water and feeding, 12 hour light/dark photocycle, at controlled room temperature $\left(25 \pm 1^{\circ} \mathrm{C}\right)$. The study was conducted according to international ethical standards of animal experimentation and approved by the Animal Research Ethics Committee of Unioeste under number 4,112.

The rats were randomized into six groups:

- G1 $(n=6)$ : rats subjected to sham ovariectomy (pseudo-ovariectomy), followed by 60 days with no intervention.
- G2 (n=6): sham ovariectomy and 60 days with no intervention. Then, the right hind limb (RHL) was immobilized for 2 weeks. Later, the rats were put on free remobilization for the same period and only came into contact with a ladder in the last 10 days.

- G3 (n=6): sham ovariectomy and 60 days with no intervention. Then, the RHL was immobilized for 2 weeks, and the rats were subsequently subjected to ladder climb exercise for 10 days, with a 2-day interval after day 5. They performed 10 climbs on week one (five days) and 20 on week two (5 days), with a 1-minute interval between climbs.

- G4 $(n=6)$ : bilateral ovariectomy and 60 days with no intervention.

- G5 $(\mathrm{n}=6)$ : bilateral ovariectomy and 60 days with no intervention. Later, immobilization and remobilization were performed similarly as for G2.

- G6 $(n=6)$ : bilateral ovariectomy and 60 days with no intervention. Then, immobilization and remobilization procedures were performed similarly as for G3.

\section{Ovariectomy and sham ovariectomy protocol}

For ovariectomy, sham ovariectomy, immobilization and euthanasia, the rats were weighed and subjected to an anesthesia protocol consisting of intraperitoneal injection of xylazine hydrochloride $(12 \mathrm{mg} / \mathrm{kg})$ and ketamine hydrochloride $(95 \mathrm{mg} / \mathrm{kg})$.

During the ovariectomy, after anesthesia, clipping was performed as well as antisepsis with iodinated alcohol in the lower abdomen, and then a longitudinal incision was made with a no. 11 surgical blade. At the peritoneal cavity, the adipose tissue was retracted until the surgeons could identify the fallopian tubes and ovaries. Suturing of the uterine horns was performed with a single 4.0 catgut suture, allowing for bilateral resection of the ovaries.

At the end of the procedure, internal and external sutures were placed using a single 4.0 catgut reabsorbable thread and 4.0 nylon, respectively. The pseudo- ovariectomy followed all surgical steps of the ovariectomy, except for removal of the ovaries. Following the surgery, the rats spent 60 days with no intervention, moving freely in the cage.

\section{Immobilization protocol}

Immobilization was carried out according to the model proposed by Booth and Kelso, ${ }^{(12)}$ modified for just one 
limb, as proposed by Matheus et al., ${ }^{(13)}$ with adaptation of the material used for the static cast brace. Prior to immobilization, anesthesia was performed, and then the RHL was wrapped in a tubular mesh with cotton bandage, from hip to ankle. Then fast-dry plaster wrap was used to mold a 50g contention brace, with the RHL at full knee extension and full plantar flexion of the ankle for the rats in G2, G3, G5 and G6.

\section{Remobilization protocol}

After the immobilization was completed, the rats in G3 and G6 were subjected to the ladder climb exercise with 10 repetitions in the first week (five days) and 20 repetitions in the second week (5 days), with 1-minute intervals between climbs and 2-day intervals between weeks. The rats in G2 and G5 were allowed free remobilization in the cage, coming into contact with a ladder at $10 \mathrm{~cm}$ from the dark box, only once, in the same period of the exercise performed with G3 and G6. The equipment used for the exercise consisted of a ladder with 67 steps separated by $1.5 \mathrm{~cm}, 20.5 \mathrm{~cm}$ wide, $118 \mathrm{~cm}$ high and with a tilt angle of $80^{\circ}$ (approximately). In the upper platform, there was a dark chamber of $28,5 \mathrm{~cm}$ (length) $\mathrm{x} 18.5 \mathrm{~cm}$ (height) $\mathrm{x}$ $15 \mathrm{~cm}$ (width), available for the rats to rest between sets of climbs, and to attract them and stimulate them to perform the exercise.

\section{Histomorphometric and histomorphological analyses}

At the end of the experiment, the rats were weighed, anesthetized and euthanized with decapitation by guillotine. Then, the right and left tibias were removed and subjected to the laboratory routine, i.e. diaphonized and embedded in paraffin; a microtome was used to make $7 \mu \mathrm{m}$ cuts, and the slides were prepared with frontal plane cuts and hematoxylin and eosin (HE) stain. The slides were photomicrographed in an Olympus DP71 ${ }^{\circledR}$ microscope at 3 points for assessment of articular cartilage, namely $\mathrm{P} 1, \mathrm{P} 2$ and $\mathrm{P} 3$, which correspond respectively to the lateral, intermediate and medial tibia. To analyze the epiphyseal plate, a photomicrograph was taken of the intermediate point. We used 200x magnification for thickness measurements of the articular cartilage and epiphyseal plate, and also for the chondrocyte count. The images were analyzed with the software Image Pro-Plus $6.0^{\circledR}$. For the histomorphological analysis, in the articular cartilage, we observed the structure and cellular organization, such as changes in the articular surface.

\section{Statistical analysis}

The study data were evaluated by comparing the results obtained for the left hind limb (LHL - control) and the RHL (immobilized), between rats in the same group and among groups. For this end, we used the software BioEstat 5.0 with values presented as mean and standard deviation. The paired Student $t$-test was conducted for comparison between the right and left sides within the same group, and one-way analysis of variance (ANOVA) was used for comparison between experimental groups, for the right and left sides. The level of statistical significance was $p \leq 0.05$.

\section{RESULTS}

\section{Articular cartilage thickness}

For the articular cartilage thickness, there was a significant decrease in the RHL compared to the LHL in G5 $(p=0.0138)$. In the intergroup comparison, significant reduction in the RHL was found for G4 when compared to G1, G2, G3 and G6, and for G5 when compared to $\mathrm{G} 1$ and $\mathrm{G} 6(\mathrm{~F}(5 ; 29)=13.88$; $\mathrm{p}<0.0001)$. The LHL showed significant decrease in G4 when compared to the other groups $(\mathrm{F}(5 ; 29)=10.72$; $\mathrm{p}<0.0001$ ) (Figure 1).

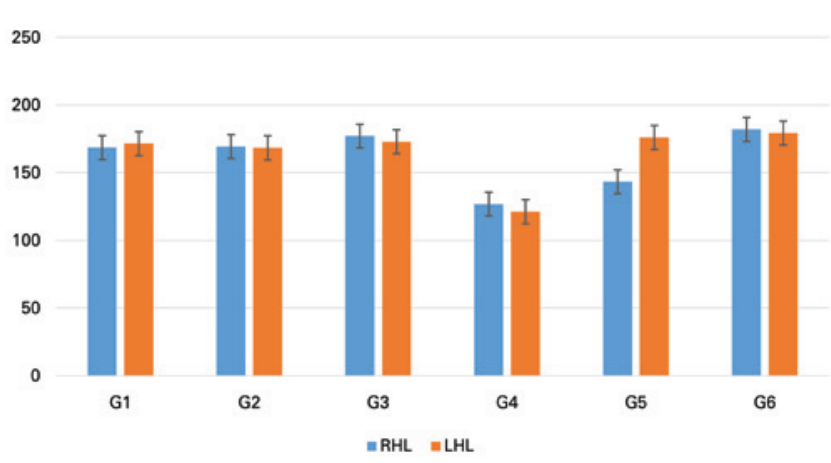

RHL: right hind limb; LHL: left hind limb.

Figure 1. Thickness of the upper articular cartilage of the tibia, compared between rats in the different study groups (G1, G2, G3, G4, G5 and G6), and between the right (target) and left (control) hind limbs. The same letter represents similarities and different letters represent significant differences between experimental groups, for the same side

\section{Epiphyseal plate thickness}

The analysis of the epiphyseal plate thickness showed a significant decrease in the RHL compared to the LHL in G5 ( $p=0.0187)$. The intergroup comparison pointed to a significant reduction in G5 compared to the other groups, as well as higher values in G1 when compared to $\mathrm{G} 4(\mathrm{~F}(5 ; 29)=14.72 ; \mathrm{p}<0.0001)$ (Figure 2$)$. 


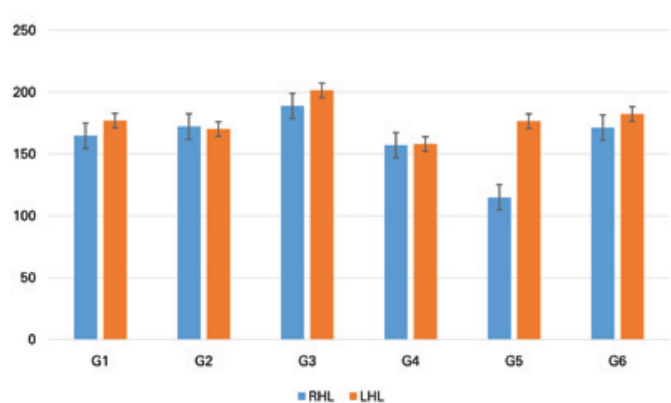

RHL: right hind limb; LHL: left hind limb.

Figure 2. Thickness of the tibial epiphyseal plate e, compared between rats in the different study groups (G1, G2, G3, G4, G5 and G6), and between the right (target) and left (control) hind limbs. The same letter represents similarities and different letters represent significant differences between experimental groups, for the same side

\section{Chondrocyte count}

As for the number of chondrocytes, G5 was the only group with a significant decrease in the RHL when compared to the LHL $(\mathrm{p}=0.0006)$. The comparison between experimental groups showed a significant decrease in G2, G4 and G5 compared to G6, as well as G1 and G3 compared to G5, when comparing the right hind limbs $(\mathrm{F}(5 ; 29)=10.16 ; \mathrm{p}<0.0001)$. When comparing the left hind limbs, G6 had higher values compared to G1, G2, G4, and G5 $(\mathrm{F}(5 ; 29)=5.11$, $\mathrm{p}<0.0021$ ) (Figure 3).

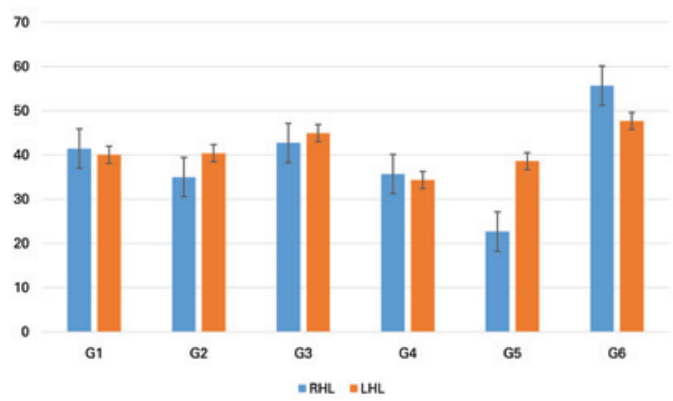

RHL: right hind limb; LHL: left hind limb.

Figure 3. Chondrocyte count in the upper articular cartilage of the tibia (unit), compared between rats in the different study groups (G1, G2, G3, G4, G5 and $\mathrm{G} 6$ ), and between the right (target) and left (control) hind limbs. The same letter represents similarities and different letters represent significant differences between experimental groups, for the same side

\section{Histomorphology}

In G1 (sham ovariectomy) and G4 (ovariectomy), no changes were observed in the thickness of the articular cartilage or the epiphyseal plate, and morphological aspects remained normal; however, in G4, there was significant reduction in the thickness and chondrocyte count, as shown in the histomorphometric analysis.
In G2 (sham ovariectomy, immobilization and free remobilization), there were areas of articular cartilage degeneration, loss of cellular organization, flocculations, decreased chondrocyte count and some granulation tissue (pannus). In G3 (sham ovariectomy, immobilization and remobilization with ladder training), there were signs of repair of cartilaginous structures, with presence of cell clones and pannus. In G5 (ovariectomy, immobilization and free remobilization), there was evidence of degeneration of the articular cartilage, presence of cracks and flocculation, discontinuity of the tidemark, and exposure of subchondral bone. In G6 (ovariectomy, immobilization and remobilization with ladder training), there was pannus formation, subcortical blood vessel invasion into the calcified zone, as well as increase in the number of isogenous groups and the thickness of the calcified zone (Figure 4).
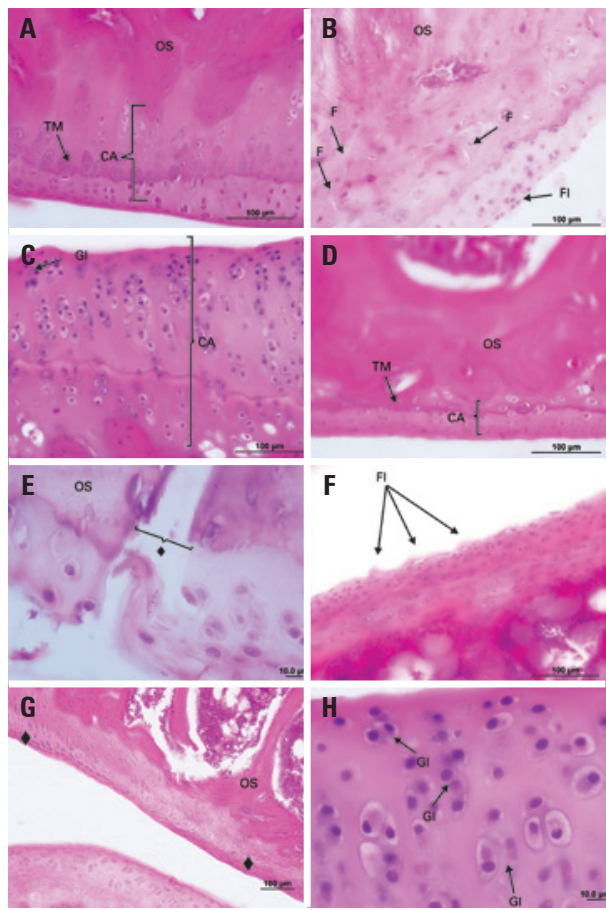

AC: articular cartilage; TM: tidemark; SB: subchondral bone; C: cracks; FI: flocculation; IG: isogenous groups Figure 4. Photomicrographs of the upper articular cartilage from the right tibia of female rats, G1 (A), G2 (B), G3 (C), G4 (D), G5 (E and F) and G6 (G and H); frontal cut; hematoxylin and eosin stain. (A) Panoramic view of the articular cartilage $(A C)$, with evidence of the tidemark (TM), and partial view of the subchondral bone (SB); (B) presence of cracks (C), flocculation (FI) and tissue disorganization; (C) increased articular cartilage thickness, hypercellularity and increased number of isogenous groups (IG); (D) decreased articular cartilage thickness and normal cellular organization; $(\mathrm{E})$ loss of articular cartilage $(\diamond)$ with subchondral bone exposure; (F) presence of flocculation (FI) on the cartilage surface; (G) restoration of the articular cartilage $(\downarrow)$ with pannus formation and presence of clones; $(\mathrm{H})$ increased articular cartilage thickness, hypercellularity and increased isogenous groups

\section{DISCUSSION}

The study results suggest that estrogen-deprivation induced by ovariectomy led to significant loss of 
articular cartilage. This hypoestrogenism changes the remodelation of cartilage tissue, ${ }^{(4)}$ favoring the onset of osteoarthrosis. ${ }^{(1,5,6,14,15)}$ This can be aggravated when immobilization is required, which may cause irreversible damage to the articular cartilage, i.e. the association of ovariectomy and immobilization may accelerate the onset of damage to the muscle and cartilage tissues. ${ }^{(16-18)}$

Immobilization leads to degeneration of the articular cartilage, with atrophic changes, decreased thickness, decreased synthesis of cartilage matrix proteoglycans, irregular cartilage surface, cartilage necrosis and ulceration, increased number of inflammatory cells, and lower total cartilage mass and volume. ${ }^{(7-9,16,19-24)}$ Some of these characteristics were observed in the group subjected to sham ovariectomy and immobilization, indicating that immobilization may have aggressive effects as early as at 2 weeks. Also, estrogen deficiency causes morphological changes in cartilage, leading to its degeneration, ${ }^{(25)}$ and this is supported by the observation of lower cartilage thickness in the left limb only in the ovariectomized group.

Exercise is indicated as a treatment for arthralgia resulting from post-menopausal osteoarthritis. ${ }^{(26)}$ This option has been the most advocated for remobilization since articular motion is capable of promoting physical, biochemical and histological changes that favor restoration of macromolecular synthesis and at least partial reversibility of cartilage damage. ${ }^{(8,27,28)}$ However, Portinho et al. ${ }^{(29)}$ used free remobilization for 15 days associated with stretching of the soleus muscle for 30 seconds three times daily, and did not see any changes in the articular cartilage thickness resulting from immobilization and remobilization. Del Carlo et al. ${ }^{(9)}$ found that immobilization for 45 days caused increase in the articular thickness and the number of chondrocytes, irregular articular surface and loss of cartilage matrix proteoglycans.

We did not find any studies investigating the cartilagerelated effects on ovariectomized rats subjected to immobization with later remobilization with ladder climb training. However, some studies suggest this type of exercise can successfully promote improvement in bone mineral density and bone stiffness, and hypertrophy of the gastrocnemius, flexor digitorum longus, plantaris and triceps muscles. ${ }^{(30-33)}$

In the present study, the sham ovariectomized rats subjected to immobilization -either free remobilization (G2) or ladder training (G3) - were able to maintain the articular cartilage and growth plate thickness as well as the number of chondrocytes at levels comparable to those of the non-immobilized limb. This was also seen with the ovariectomized rats subjected to immobilization and remobilization with ladder training (G6). However, the same benefit was not seen in G5, which demonstrates that immobilization leads to significant losses of cartilage tissue in ovariectomized rats. Differently from the ladder training (G6), free remobilization was unable to reverse the deleterious effects on the cartilage tissue, probably because this would require weight-bearing on the joint. Remobilization with weight bearing on the joint promotes the secretion of proteoglycans in the matrix, allowing for restoration of the cartilage structure. ${ }^{(8)}$ Treadmill exercise was shown to be useful in ovariectomized rats to protect the articular cartilage. ${ }^{(34)}$

Damage to the extracelular matrix and complete degradation of the articular cartilage may result from the increased activity of matrix metalloproteinases. ${ }^{(35)} \mathrm{In}$ the morphological analysis, we observed predominance of degraded areas, especially in G5 (ovariectomy, immobilization and free remobilization), and predominance of articular cartilage restoration in G2, G3 and G6, though more evident in the last two, due to the repairing effect of physical exercise. There was mainly the presence of pannus, increase in isogenic groups, and cell clones resulting from inflammation of joint tissues. ${ }^{(36)}$ These reactions reflect the restoration of the damaged articular cartilage, due to the proliferative capacity of chondrocytes and repair of the subchondral bone, with increased nutritional support in the region promoted by remobilization programs..$^{(9,36)}$

\section{CONCLUSION}

In short, ovariectomy associated with immobilization was observed to cause thinning of the articular cartilage and growth plate, decrease in the number of chondrocytes, articular cartilage degeneration, loss of cellular organization, flocculation and pannus. Free remobilization was not able to reverse the damage to the cartilage tissue of the tibia in ovariectomized and immobilized rats, but reversibility was achieved with ladder-based remobilization, evidenced by improvement of morphometric and morphological parameters with signs of repaired cartilaginous structures observed by the presence of cell clones and pannus, subcortical blood vessel invasion into the calcified zone, increased number of isogenous groups and increased thickness of the calcified zone.

\section{REFERENCES}

1. Claassen H, Schlüter M, Schünke M, Kurz B. Influence of 17beta-estradiol and insulin on type II collagen and protein synthesis of articular chondrocytes. Bone. 2006:39(2):310-7.

2. The North American Menopause Society. The menopause guidebook. 7a ed 2012. $89 p$ 
3. Li S, Luo Q, Huang L, Hu Y, Xia Q, He C. Effects of pulsed electromagnetic fields on cartilage apoptosis signalling pathways in ovariectomised rats. Int Orthop. 2011;35(12):1875-82.

4. Høegh-Andersen P, Tankó LB, Andersen TL, Lundberg CV, Mo JA, Heegaard AM, et al. Ovariectomized rats as a model of postmenopausal osteoarthritis: validation and application. Arthritis Res Ther. 2004;6(2):R169-80.

5. Sniekers YH, Weinans H, Bierma-Zeinstra SM, van Leeuwen JP, van Osch GJ. Animal models for osteoarthritis: the effect of ovariectomy and estrogen treatment - a systematic approach. Osteartrites Cartilage. 2008;16(5):533-41. Review.

6. Talwar R, Wong B, Svoboda K, Harper R. Effects of estrogen on chondrocyte proliferation and collagen synthesis in skeletally mature articular cartilage. $\mathrm{J}$ Oral Maxillofac Surg. 2006;64(4):600-9.

7. Kunz RI, Coradini JG, Silva LI, Bertolini GR, Brancalhão RM, Ribeiro LF. Effects of immobilization and remobilization on the ankle joint in Wistar rats. Braz J Med Biol Res. J Med Biol Res. 2014;47(10):842-9.

8. Brandt KD. Response of joint structures to inactivity and to reloading after immobilization. Arthritis Rheum. 2003;49(2):267-71. Review.

9. Del Carlo R, Galvão M, Viloria M, Natali A, Barbosa A, Monteiro B, et al. Imobilização prolongada e remobilização da articulação fêmoro-tíbio-patelar de ratos: estudo clínico e microscópico. Arq Bras Med Vet Zootec. 2007; 59(2):363-70.

10. Ju YI, Sone T, Okamoto T, Fukunaga M. Jump exercise during remobilization restores integrity of the trabecular architecture after tail suspension in young rats. J Appl Physiol. 2008;104(6):1594-600.

11. Ocarino N, Silva J, Santiago L, Rocha C, Marubayashi U, Serakides R. Treadmill training before and/or after ovariectomy is more effective in preventing osteopenia in adult female rats. Sci Sports. 2009;24(1):52-5.

12. Booth FW, Kelso JR. Effect of hind-limb immobilization on contractile and histochemical properties of skeletal muscle. Pflugers Arch. 1973;342(3):231-8.

13. Matheus JP, Gomide LB, Oliveira JG, Volpon JB, Shimano AC. Efeitos da estimulação elétrica neuromuscular durante a imobilização nas propriedades mecânicas do músculo esquelético. Rev Bras Med Esporte. 2007;13(1):55-9.

14. Richette P, Corvol M, Bardin T. Estrogens, cartilage, and osteoarthritis. Joint Bone Spine. 2003;70(4):257-62. Review.

15. Roman-Blas JA, Castañeda S, Largo R, Herrero-Beaumont G. Osteoarthritis associated with estrogen deficiency. Arthritis Res Ther. 2009;11(5):241. Review.

16. Ando A, Suda H, Hagiwara Y, Onoda Y, Chimoto E, Saijo Y, et al. Reversibility of immobilization-induced articular cartilage degeneration after remobilization in rat knee joints. Tohoku J Exp Med. 2011;224(2):77-85.

17. Vanwanseele B, Lucchinetti E, Stüssi E. The effects of immobilization on the characteristics of articular cartilage: current concepts and future directions. Osteartrites Cartilage. 2002;10(5):408-19. Review.

18. Cavolina JM, Evans GL, Harris SA, Zhang M, Westerlind KC, Turner RT. The effects of orbital spaceflight on bone histomorphometry and messenger ribonucleic acid levels for bone matrix proteins and skeletal signaling peptides in ovariectomized growing rats. Endocrinology. 1997;138(4):1567-76.

19. Christensen B, Dyrberg E, Aagaard P, Kjaer M, Langberg H. Short-term immobilization and recovery affect skeletal muscle but not collagen tissue turnover in humans. J Appl Physiol (1985). 2008;105(6):1845-51.
20. Christensen B, Dyrberg E, Aagaard P, Enehjelm S, Krogsgaard M, Kjaer M, et al. Effects of long-term immobilization and recovery on human triceps surae and collagen turnover in the Achilles tendon in patients with healing ankle fracture. J Appl Physiol (1985). 2008;105(2):420-6.

21. Arakaki K, Kitamura N, Kurokawa T, Onodera S, Kanaya F, Gong JP, et al. Joint immobilization inhibits spontaneous hyaline cartilage regeneration induced by a novel double-network gel implantation. J Mater Sci Mater Med. 2011; 22(2):417-25.

22. Hagiwara Y, Ando A, Chimoto E, Saijo Y, Ohmori-Matsuda K, Itoi E. Changes of articular cartilage after immobilization in a rat knee contracture model. $J$ Orthop Res. 2009;27(2):236-42.

23. Iqbal K. Effects of immobilization on chondrocytes and pericellular matrix in articular cartilage of patella in rats. J Morphol Sci. 2012;29(1):8-11.

24. Iqbal $K$, Khan Y, Minhas LA. Effects of immobilization on thickness of superficial zone of articular cartilage of patella in rats. Indian J Orthop. 2012;46(4):391-4.

25. Wolff RB, Gomes RC, do Amaral VC, da Silva PL, Simoncini T, Prosdocimi $\mathrm{FC}$, et al. Effects of hyperprolactinemia on the tibial epiphyseal plate of mice treated with sex hormones. Gynecol Endocrinol. 2015;1-4. [Epub ahead of pint]

26. Magliano M. Menopausal arthralgia: fact or fiction. Maturitas. 2010;67(1): 29-33. Review.

27. Narmoneva DA, Cheung HS, Wang JY, Howell DS, Setton LA. Altered swelling behavior of femoral cartilage following joint immobilization in a canine model. J Orthop Res. 2002;20(1):83-91.

28. Leroux MA, Cheung HS, Bau JY, Wang JY, Howell DS, Setton LA. Altered mechanics and histomorphometry of canine tibial cartilage following joint immobilization. Osteartrites Cartilage. 2001;9(7):633-40.

29. Portinho D, Boin VG, Bertolini GR. Efeitos Sobre o Tecido Ósseo e Cartilagem Articular Provocados Pela Imobilização e Remobilização em Ratos Wistar. Rev Bras Med Esporte. 2008;14(5):408-11.

30. Cassilhas RE, Reis IT, Venâncio D, Fernandes J, Tufik S, Mello MT. Animal model for progressive resistance exercise : a detailed description of model and its implications for basic research in exercise. Motriz. 2013;19(1):178-84.

31. Nascimento V, Krause Neto W, Gonçalves L, Maifrino LB, Souza RR, Gama EF. Morphoquantitative analysis revealed Triceps Brachialis muscle hypertrophy by specific Resistance training equipment in rats. J Morphol Sci. 2013; 30(4):276-80.

32. Oliveira $M$, Oliveira B, Peres $M$, Coêlho J, Florindo P, Louzada M. Análise densitométrica e biomecânica de tíbias de ratos submetidos à suspensão pela cauda e exercício físico resistido. Arch Health Invest. 2013;2:292.

33. Oliveira BR, Silva ME, Medeiros RA, Apolinário-Coêlho J. A influência do treinamento físico resistido no tecido ósseo de ratos osteopênicos induzidos por suspensão pela cauda. Arch Heal Investig. 2013;2(2):3009.

34. Chang $\mathrm{TK}$, Huang $\mathrm{CH}$, Huang $\mathrm{CH}$, Chen $\mathrm{HC}$, Cheng $\mathrm{CK}$. The influence of long-term treadmill exercise on bone mass and articular cartilage in ovariectomized rats. BMC Musculoskelet Disord. 2010;11(185).

35. Nagase $\mathrm{H}$, Kashiwagi M. Aggrecanases and cartilage matrix degradation. Arthritis Res Ther. 2003;5(2):94-103. Review.

36. Gonçalves G, Melo EG, Gomes MG, Nunes VA, Rezende CM. Effects of chondroitin sulfate and sodium hyaluronate on chondrocytes and extracellular matrix of articular cartilage in dogs with degenerative joint disease. Arq Bras Med Vet Zootec. 2008;60(1):93-102. 